\title{
84. 山口県「きらら博」の照明設備
}

\author{
吉満 伸一 \\ （八千代エンジニヤリング株式会社）
}

\author{
藤田 淳一 中込 浩之 \\ （小糸工業株式会社）
}

\section{1. はじめに}

新しい世紀がはじまる西暦2001年7月14日から9月30日まで、山口県阿知須（あじす）干拓地で

「いのちきらめく未来へ」をテーマに「山口きらら博」が開催された。会場内に開催のメインテーマ である「いのち」を想像させるイルミネーションや街路照明を設置した。

ここでは、主に屋外に設置した照明設備について報告する。

\section{2. 照明設備の概要}

\section{(1) センター道路}

会場に向かうセンター道路はシンプルで落ち着いた雰囲気 を感じるデザインとし、自然石混入コンクリート照明柱を採 用している。照明器具も海からの風を考慮し、アルミダイカ スト製の軽量でコンパクトなものを採用している（図1）。 車の通行がメインであることから、光源をNHT180LSとし、 十分な明るさと円滑な誘導効果を確保している。36基

\section{(2) 月の海}

自然そのものの海水を引き込んだラグーンには、生命の誕 生をイメージしたLEDイルミネーションを設置した（図2）。 LEDを光源とし高寿命はもちろん7色の発光色を楽しむことが 出来る。自然の海水を取り入れた月の海は、潮の満ち引きに より水面が上下するため、照明器具が海水に浸水する可能性 がある。そのため、灯具上面 $1.0 \mathrm{~m}$ (最大水深) まで対応可能 な器具構造とした（図3）。1基（光源4台内蔵）

\section{（3）園内園路 ·外周道路}

会場内にある施設は主に屋外通路を利用し移動するため、 防犯や安全な人の移動を補助する街路照明（ $\mathrm{H}=5.0 \mathrm{~m} ）$ を設 置している（図3）。照明ポールはP H S のアンテナや音声案 内スピーカーを取り付けたアルミ製複合ポールもある。光源 には高演色形高圧ナトリウムランプ140W(Ra85)を採用し、歩 行者照明に適した演色性を確保している。65基

\section{3. まとめ}

会場である阿知須干拓地の南工区 は「スポーツ交流ゾーン」、北工区 の一部は野鳥観測が出来る「自然観 察公園」として生まれ変わっている 。今回の照明設備はイベント会場と しての演出や機能はもちろんである が、恒久整備としての「時代ととも に成長し、変化していく公園」とい うコンセプトを受けて無䭾のない機 能美とうい言葉に相応しい設備に仕 上がっていると感じる。本事例が有 効的に活用され、良好な照明事例創 出に役立つことを期待する。

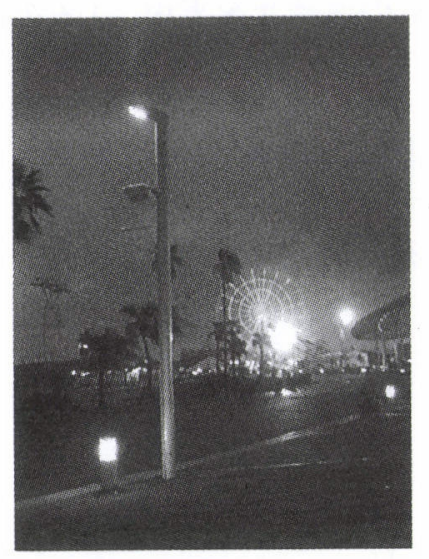

図 4 園内園路

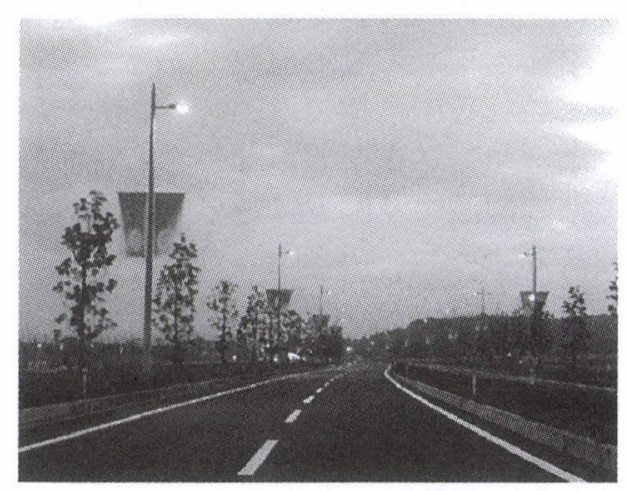

図 1 センター道路
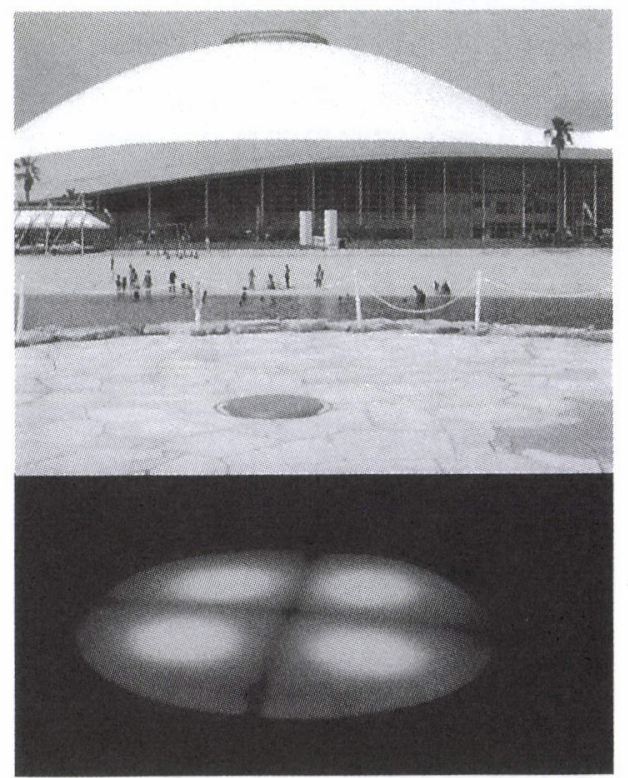

図 2 月の海

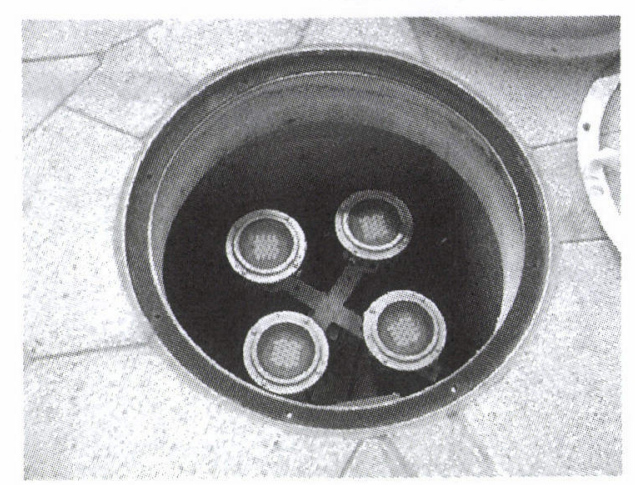

図 3 器具取付状況

Lighting equipment of Yamaguchi Prefecture "kirara expo" Shinichi Yoshimitsu, Junichi Fujita, Hiroyuki Nakagomi 